\title{
AKTIVITAS ANTIBAKTERI DAN ANTI-UV BEBERAPA ASCIDIAN DARI PERAIRAN PANGALISANG BUNAKEN
}

\author{
(Antibacterial and anti-UV activity of ascidians from the Pangalisang waters, \\ Bunaken)
}

\author{
Yuliana Macpal ${ }^{{ }^{*}}$, Veibe Warouw ${ }^{1}$, Deiske A. Sumilat ${ }^{1}$, James J.H. Paulus ${ }^{1}$, \\ Natalie D.C. Rumampuk ${ }^{1,}$ Reni L. Kreckhoff ${ }^{2}$
}

1. Program Studi IImu Kelautan, FPIK, UNSRAT

2. Program Studi Budidaya Perairan, FPIK, UNSRAT

*e-mail : veibe.warouw@yahoo.co.id

\begin{abstract}
Ascidians are sesile marine invertebrates that have bioactive compounds such as antibacterial and anti-UV. The purpose of this study is to determine the antibacterial activity against Escherichia coli and Staphylococcus aureus bacteria and to test the anti-UV activity of the ascidian water fraction. Antibacterial activity test was carried out using the diffusion method (disc diffusion Kirby \& Bauer) and the water fraction of ascidian that showing antibacterial activity tested in a UV spectrophotometer to see the anti-UV activity. Results of the study were obtained 4 types of ascidians extracted from partitioned into water fraction, $n$-hexane fraction, methanol fraction. All three fractions were tested for antibacterial activity and the result showed that there were antibacterial activities of ascidian extract Clavelina sp. against both test bacteria with inhibition of $S$. aureus and E. coli with strong categories. Ascidian Phlebobranch sp. showed the presence of antibacterial activity with inhibition of $S$. aureus and $E$. coli with very strong categories $(16,6 \mathrm{~mm})$. extract Eudistoma sp. showed the presence of antibacterial activity with inhibition $S$. aureus and $E$. coli in the medium category $(9 \mathrm{~mm})$. The water fraction found active in antibacterial testing is then tested using a UV spectrophotometer for anti UV testing, the result show that water fraction of the four ascidians can absorb UV-B (290-320nm) and UV-A ( 320-400nm).
\end{abstract}

Keywords : Ascidian, Antibacterial, Partition, Anti- UV.

Ascidian adalah avertebrata laut yang mempunyai senyawa bioaktif seperti antibakteri dan anti-UV. Tujuan dari penelitian ini yaitu untuk mengetahui aktivitas antibakteri terhadap bakteri Escherichia coli dan Staphylococcus aureus dan aktivitas anti-UV dari fraksi air ascidian. Pengujian antibakteri dilakukan dengan metode difusi agar (discdiffusion Kirby and Bauer) dan fraksi air ascidian yang menunjukkan aktivitas antibakterinya kemudian diujikan dalam UV spektofotometer untuk melihat aktivitas anti-UV. Hasil penelitian didapatkan 4 jenis ascidian yang diekstrak dan dipartisi menjadi fraksi air, fraksi n-heksana, fraksi methanol. Ketiga fraksi diuji aktivitas antibakterinya dan hasilnya menunjukan bahwa terdapat aktivitas antibakteri terhadap Ekstrak ascidian Clavelina sp. menunjukkan adanya aktivitas antibakteri terhadap kedua bakteri uji dengan daya hambat bakteri $S$. aureus dan E. coli dengan kategori Kuat. Sampel ekstrak ascidian Phlebobranch sp. menunjukkan adanya aktivitas antibakteri dengan daya hambat bakteri $S$. aureus dan E. coli dengan kategori sangat Kuat $(16,6 \mathrm{~mm})$. Sampel ekstrak ascidian Eudistoma sp. menunjukkan adanya aktivitas antibakteri dengan daya hambat bakteri $S$. aureus dan E. coli dengan kategori sedang $(9 \mathrm{~mm})$. Fraksi air yang ditemukan aktif dalam pengujian antibakteri selanjutnya diuji menggunakan UV spektrofotometer untuk pengujian anti-UV, hasil menunjukan bahwa fraksi air keempat jenis ascidian dapat menyerap UV-B $(\lambda$ 290-320 nm) dan UV-A $(\lambda$ 320-400 nm).

Kata kunci : Ascidian, Antibakteri, Partisi, Anti-UV. 


\section{PENDAHULUAN}

Perairan Indonesia memiliki keanekaragaman hayati yang tinggi sehingga besar potensinya untuk dieksplorasi dan dieksploitasi sumberdaya alam yang ada, terutama organisme laut yang dapat dijadikan sebagai bahan makanan, sumber bahan pembuatan kosmetik juga obat-obatan seperti ascidian, spons, moluska. Lingkungan laut merupakan sumber yang besar dari produk alam yang memiliki bentuk yang unik termasuk pada ascidian yang merupakan organisme yang hidup dalam perairan. (Bara $d k k$, 2015).

Ascidian telah banyak menarik perhatian sebagai salah satu sumber zat antikanker, antivirus, dan antitumor. Sebagai contohnya di Thailand telah ditemukan alkaloid (ectinascidin) yang berasal dari Ecteinascidia thurstoni yang bersifat sitotoksik untuk sel kanker payudara, paruparu, dan jaringan nasofaring. Adapula metabolit ascidian yang berpotensi sebagai antifouling yaitu alkaloid eudistomin dari jenis Eudistoma olivaceum, dan pelindung UV serta antioksidan dan berupa asam amino seperti mycosporine (McClintock dan Baker, 2001).
Adapun dalam penelitian ini pengujian antibakteri akan mengunakan bakteri Escherichia coli dan Staphylococcus aureus, menurut Munif (2009) E. coli merupakan bakteri yang sering menimbulkan penyakit (diare) pada manusia. Sedangkan bakteri $S$. aureus merupakan bakteri yang dapat menyebabkan infeksi pada luka dan furunkel (Yuwono, 2012).

$$
\text { Lokasi Penelitian Perairan }
$$

Pangalisang Bunaken, Manado Sulawesi Utara yang memiliki alam bawah laut dengan keanekaragaman yang tinggi sehingga perlu dilakukan ekplorasi dan eksploitasi terhadap metabolit sekunder yang dihasilkan organisme ascidian, dalam penelitian ini organisme ascidian diekstrak dan dipartisi untuk diuji aktivitas antibakteri menggunakan metode difusi agar dan uji aktivitas anti-UV menggunakan UV spektrofotometer. 


\section{METODE PENELITIAN}

\section{Waktu dan Tempat Penelitian}

Tempat pengambilan sampel pada Perairan Pangalisang Bunaken, kemudian penelitian dilanjutkan di Laboratorium Biologi Molekuler dan Farmasitika Laut, FPIK UNSRAT untuk kegiatan ekstraksi, partisi, serta pengujian aktivitas antibakteri dan Laboraturium Kimia Analisis Farmasi, FMIPA UNSRAT untuk pengujian aktivitas anti-UV menggunakan alat UV Spektrofotometer.

\section{Pengambilan Sampel Ascidi}

Sampel ascidian diperoleh dengan Penyelaman (diving) pada ke dalaman sekitar 5-7 m menggunakan satu set alat selam. Sampel yang diambil kemudian di potong kecil-kecil berbentuk dadu, kemudian direndam dalam larutan etanol $95 \%$ dan dibawa ke laboratorium Biologi Molekuler dan Farmasitika Laut, FPIK UNSRAT.

\section{Alat dan Bahan}

Alat-alat yang digunakan dalam penelitiian ini adalah botol, timbangan, evaporasi, satu set rotary vacuum evaporator, corong pisah, statif, klem, elenmeyer, cawan petri, mikropipet, kertas cakram, laminar air flow, oven, autoklaf, mistar, spatula, almunium foil, dan spektrofotometer UV-Vis.

\section{Sterilisasi Alat Dan Bahan}

Alat-alat gelas yang digunakan dalam pengujian antibakteri dicuci bersih dan dikeringkan lalu dibungkus dengan kertas alumunium foil dan dimasukan kedalam oven selama 2 jam pada suhu $150^{\circ} \mathrm{C}$ (sterilisasi kering) (Ortez, 2015).

\section{Ekstraksi Ascidian}

Sampel ascidian dimaserasi dengan pelarut etanol dan diinkubasi selama 24 jam. Dilakukan sebanyak 3 kali. Hasil filtrat kemudian diuapkan menggunakan rotary vacuum evaporator pada suhu $40^{\circ} \mathrm{C}$ hingga diperoleh ekstrak kasar.

\section{Partisi}

Pelarut pertama yaitu aquades dicampur dengan ekstrak kasar dari ascidian sebanyak $10 \mathrm{~g}$ dan dituang pelarut etil asetat sebanyak $100 \mathrm{ml}$. perbandingan pelarut dalam corong pisah adalah (1:1), kemudian kocok corong pisah secara horizontal dan didiamkan selama 5 menit sampai dua larutan terpisah membentuk 2 lapisan. Ketika kedua pelarut sudah terpisah, kran corong pisah dibuka dan 
pelarut yang paling bawah aquades $\quad 50 \quad \mathrm{ml}$. selanjutnya ditampung pada erlenmeyer dihomogenkan menggunakan sehingga didaptkan fraksi pertama yaitu fraksi air selanjutnya pelarut yang berada di atas fraksi air yaitu fraksi etil asetat ditampung ke dalam erlenmeyer yang berbeda. Fraksi etil asetat selanjutnya dievaporasi. Kegiatan partisi selanjutnya dilakukan dengan menuangkan pelarut metanol $100 \mathrm{ml}$ ke dalam corong pisah dan diikuti oleh hasil evaporasi etil asetat, kemudian ditambahkan pelarut n-heksana 100 ml. Setelah terbentuk lapisan, kran corong pisah dibuka dan ditampung lapisan pertama, yaitu fraksi metanol pada Erlenmeyer, kemudian lapisan diatas yaitu fraksi n-heksana ditampung pada erlenmeyer berbeda. Fraksi air, metanol dan nheksana masing-masing dievaporasi untuk pengujian antibakteri dan antiUV. Alur partisi yang dilakukan mengikuti metode Opa dkk. (2018) yang telah dimodifikasi.

\section{Pembuatan Media Cair B1}

Media cair B1 dibuat sebanyak 2 media (erlenmeyer) untuk kultur bakteri uji. Banyaknya bahan dalam pembuatan media cair untuk tiap erlenmeyer yaitu pepton 0,25 g, ekstrak daging (meat extract) $0,15 \mathrm{~g}$, natrium klorida $(\mathrm{NaCl}) \quad 0,15 \mathrm{~g}$, dan

spatula, kemudian ditutup dan dibungkus menggunakan alumunium foil untuk diautoklaf pada suhu $121^{\circ} \mathrm{C}$ selama kurang lebih 15 menit.

\section{Kultur Bakteri}

Bakteri uji S. aureus dan E. coli yang diperoleh dari Laboratorium Biologi Molekuler dan Farmasetika Laut FPIK UNSRAT. Untuk pengkulturan, bakteri $E$. coli dan $S$. aureus diambil menggunakan jarum ose dengan cara digerus dan dimasukan ke dalam erlenmeyer yang telah berisikan media cair yang dibuat sebelumnya, kemudian dibungkus menggunakan kertas almunium foil dan diinkubasi selama 1x24 jam.

\section{Pembuatan Media Padat B1}

Media padat B1 dibuat pada 2 erlemeyer untuk masing-masing bakteri uji. Dengan komposisi tiap erlenmeyer pepton $1 \mathrm{~g}$, ekstrak daging (meat extract) 0,6 g, $\mathrm{NaCl} 0,6$ gram, agar $3 \mathrm{~g}$ dan air sebanyak 200 $\mathrm{ml}$. Seluruh bahan dihomogenkan dan dibungkus dengan kertas alumunium foil lalu disterilkan menggunakan autoklaf pada suhu $121^{\circ} \mathrm{C}$ selama \pm 15 menit, selanjutnya media dibiarkan sampai 
hangat lalu masukan bateri yang telah dikultur dengan media cair B1 menggunakan mikropipet berukuran $1000 \mu \mathrm{l}$ sebanyak $2 \mathrm{ml}$, kemudian ditutup menggunkan alumunium foil dan dituangkan ke dalam cawan petri yang sudah disterilkan.

\section{Pembuatan Kontrol}

Kontrol positif dan negative diperlukan untuk melihat ada tidaknya zona hambat atau aktivitas antibakteri dari ekstrak kasar dan ketiga fraksi yang ada. Adapun pembuatan kontrol positif yaitu 100 mg kloramfenikol dilarutkan dalam 1 $\mathrm{ml}$ air, dan kontrol negatif digunakan pelarut methanol $95 \%$.

\section{Pengujian Aktivitas Antibakteri}

Pengujian akitivitas antibakteri digunakan konsentrasi $100 \mathrm{mg} / \mathrm{ml}$ untuk ekstrak kasar dan $10 \mathrm{mg} / \mathrm{ml}$ untuk setiap fraksi. Kemudian diambil $20 \mu \mathrm{l}$ pada masing-masing ekstrak kasar, ketiga fraksi, kontrol positif, dan kontrol negatif menggunakan mikropipet dan ditotolkan pada kertas cakram. Selanjutnya kertas cakram diletakan pada media uji yang telah diberi label, kemudian cawan petri ditutup dan diinkubasi selama 24 jam.. Setelah masa inkubasi berakhir dilakukan pengamatan pada cawan petri. Jika daerah pada sekitar cakram menunjukan aktivitas antibakteri maka terdapat zona hambat/zona bening di sekitar kertas cakram yang terbentuk kemudian diukur diameternya dalam satuan $(\mathrm{mm})$ menggunakan mistar berskala.

\section{Pengujian Anti-UV}

Fraksi ascidian yang akan diuji pada UV spektrofotometer untuk mengetahui apakah organisme ascidian tersebut memiliki senyawa anti-UV pertama, melarutkan ekstrak ascidian kedalam pelarut metanol 20 $\%$, selanjutnya dimasukkan $1 / 4$ bagian dalam suprasil kuvet (Warouw dan Losung, 2015). Kemudian diuji pada alat UV spektrofotometer dengan panjang gelombang 290-400 nm. Selanjunya diamati banyaknya sinar yang diabsorbsi

\section{HASIL DAN PEMBAHASAN}

\section{Identifikasi Sampel Ascidian}

Hasil identifikasi dari keempat ascidian yang diperoleh yaitu Rhopalaea sp., Clavelina sp., Eudistoma sp., dan Phelebobranch sp. (Gambar 1). 

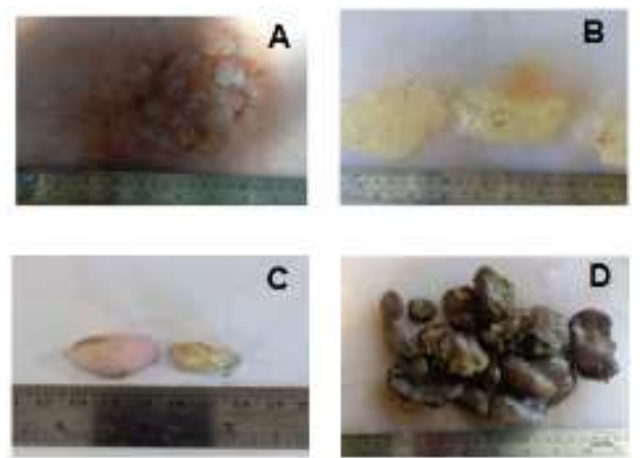

Gambar 1. Sampel Ascidian (A) Rhopalaea sp. (B) Clavelina sp. (C) Eudistoma sp. (D) Phelebobranch sp.

\section{Ekstrak Kasar}

Setelah dimaserasi sebanyak 3 kali dan dievaporasi, diperoleh ekstrak kasar kemudian ditimbang menggunakan timbangan analitik dapat dilihat pada ( tabel 1).

Tabel 1. Sampel Ekstraksi Ascidian

\begin{tabular}{|l|c|}
\hline \multicolumn{1}{|c|}{ Sampel Ascidian } & Berat Ekstrak Kasar \\
\hline Rhopalaea sp. (ASB 1) & $20 \mathrm{~g}$ \\
\hline Clavelina sp. (ASB 2) & $15 \mathrm{~g}$ \\
\hline Eudistoma sp. (ASB 3) & $18 \mathrm{~g}$ \\
\hline Phlebobranch sp. (ASB 4) & $14 \mathrm{~g}$ \\
\hline
\end{tabular}

\section{Partisi}

Hasil ekstrak kemudian diparisi dengan hasil akhir diperoleh 3 jenis fraksi, yaitu fraksi air, fraksi methanol, fraksi n-heksana. Masing- masing dievaporasi dan ditimbang menggunakan timbangan analitik (Tabel 2) .

Tabel 2. Berat Fraksi Ascidian

\begin{tabular}{|l|c|c|c|}
\hline \multicolumn{1}{|c|}{ Sampel Ascidian } & $\begin{array}{c}\text { Fraksi } \\
\text { Air }\end{array}$ & $\begin{array}{c}\text { Fraksi } \\
\text { Methanol }\end{array}$ & $\begin{array}{c}\text { Fraksi } \\
\text { n-heksana }\end{array}$ \\
\hline Rhopalaea sp. (ASB 1) & $2000 \mathrm{mg}$ & $300 \mathrm{mg}$ & $260 \mathrm{mg}$ \\
\hline Clavelina sp. (ASB 2) & $1900 \mathrm{mg}$ & $200 \mathrm{mg}$ & $105 \mathrm{mg}$ \\
\hline Eudistoma sp. (ASB 3) & $1200 \mathrm{mg}$ & $250 \mathrm{mg}$ & $370 \mathrm{mg}$ \\
\hline Phlebobranch sp. (ASB 4) & $1500 \mathrm{mg}$ & $230 \mathrm{mg}$ & $270 \mathrm{mg}$ \\
\hline
\end{tabular}

\section{Pengujian Aktivitas Anti Bakteri}

\section{Rhopalaea sp. (ASB 1)}

Aktivitas antibakteri pada media bakteri $S$. aureus dan $E$. coli (Gambar 2) tidak menunjukan adanya zona hambat atau aktivitas antibakteri.

\section{Clavelina sp. (ASB2)}

Aktivitas antibakteri pada media bakteri $S$. aureus dan E. coli (Gambar 3) yang menujukan diameter zona hambat yaitu pada 
fraksi air, fraksi methanol dan ekstrak etanol .

\section{Eudistoma sp. (ASB3)}

Aktivitas antibakteri pada media bakteri S.aureus dan E.coli (Gambar 4) hanya fraksi air, fraksi metanol, yang menunjukan diameter zona hambat.

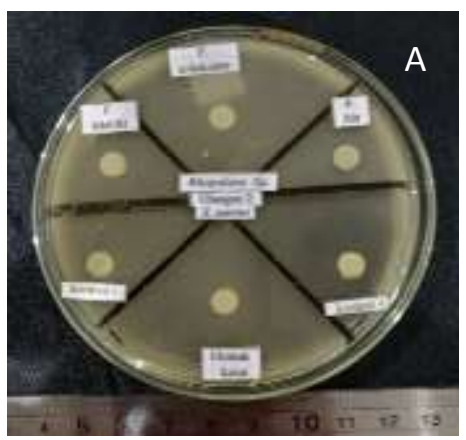

\section{Phlebobranch sp. (ASB4)}

Aktivitas antibakteri pada media S. aureus dan E. coli (Gambar 5) hanya fraksi metanol yang menunjukan diameter zona hambat. Kemudian seluruh hasil dirata-ratakan dan hasilnya dapat dilihat pada Tabel 3 dan Gambar 6 .

Gambar 2. Hasil pengujian antibakteri Rhopalaea sp. terhadap media bakteri (A) S. aureus (B) E. coli
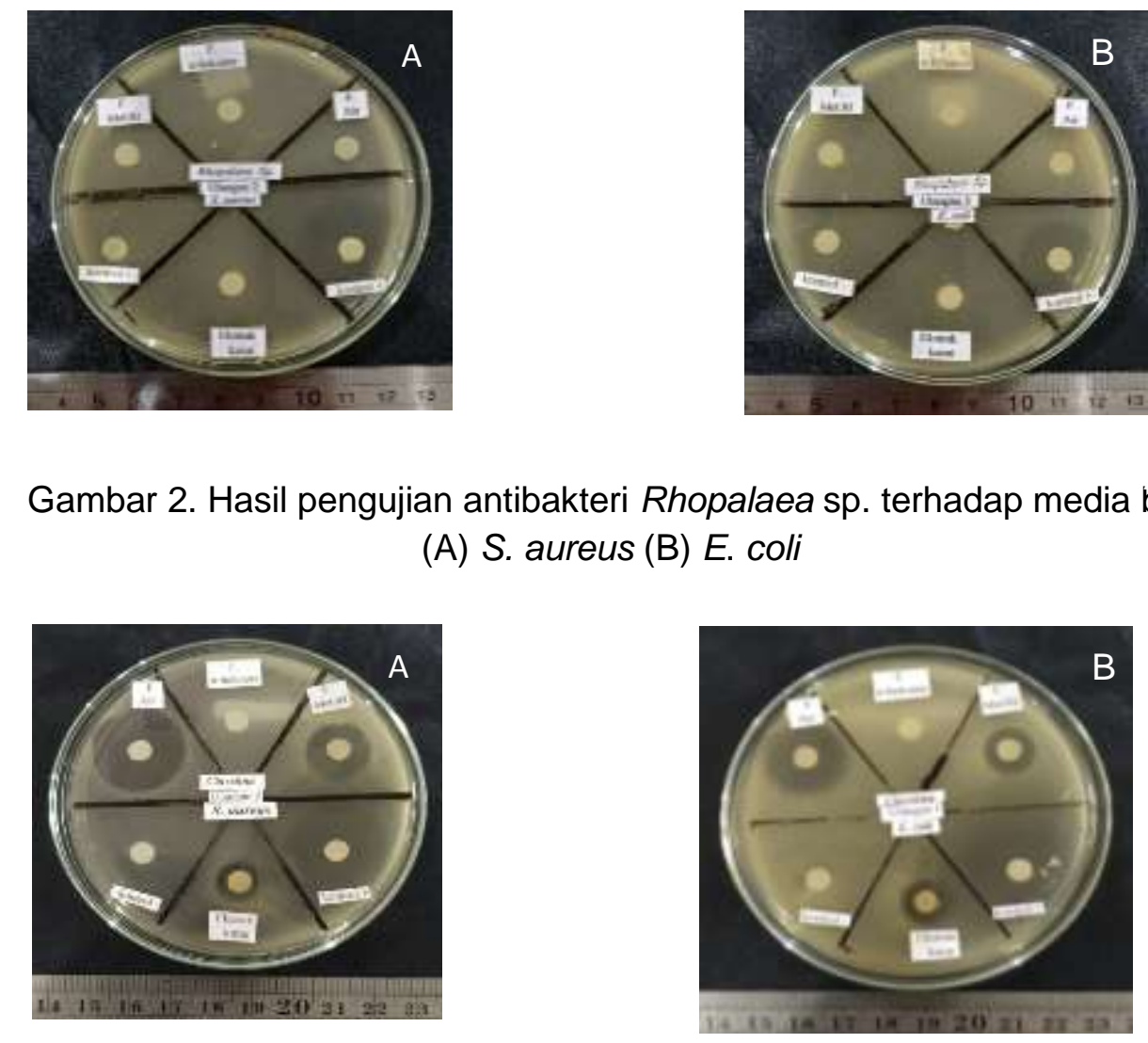
(A) S. aureus (B) E. coli

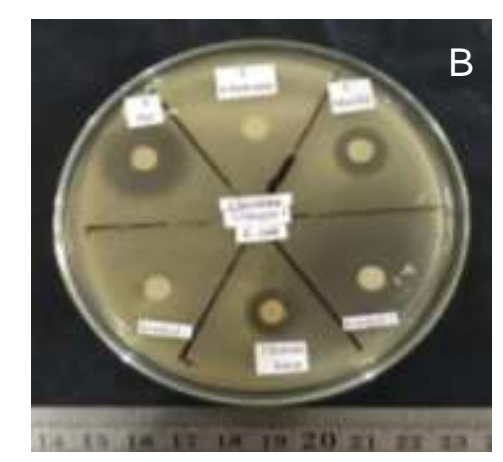

Gambar 3 . Hasil pengujian antibakteri Clavelina sp. terhadap media bakteri

(A) S. aureus (B) E. coli 

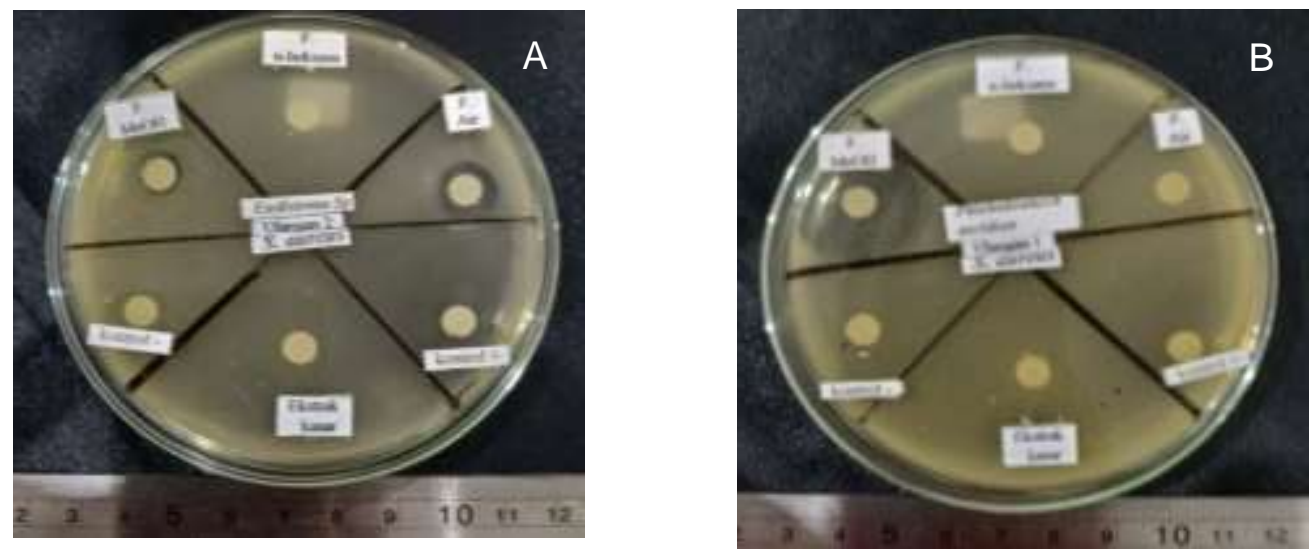

Gambar 4. Hasil pengujian antibakteri Eudistoma sp. terhadap media uji (A) S. aureus (B) E. coli
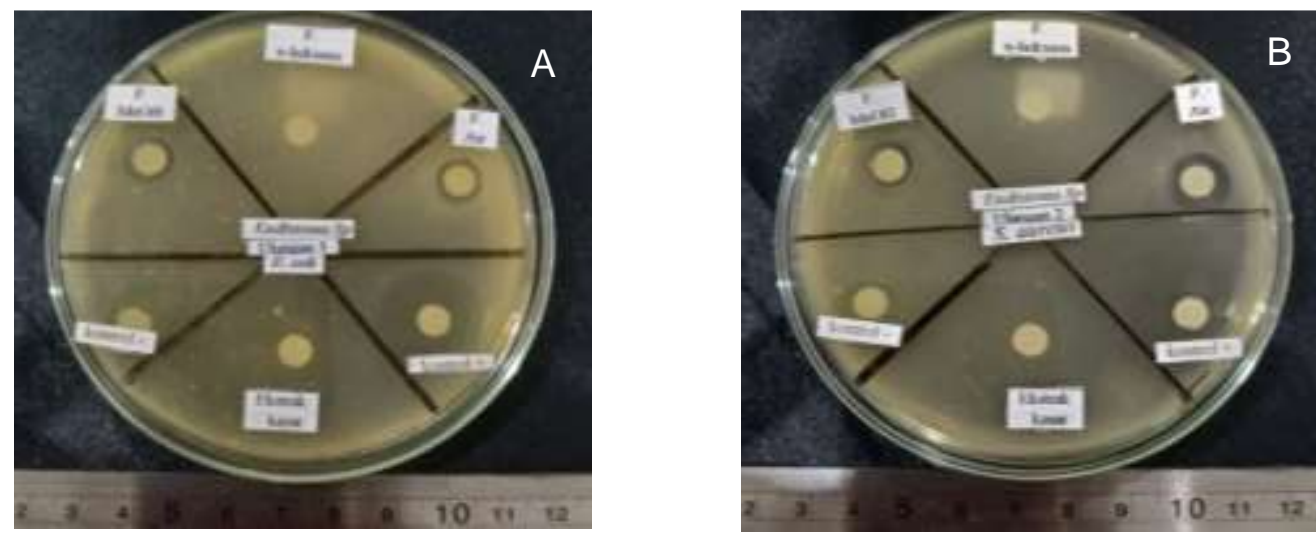

Gambar 5. Hasil pengujian antibakteri Phelebranch sp. terhadap media uji (A) S. aureus (B) E. coli

Tabel 3. Rerata zona hambat Ascidian

\begin{tabular}{|l|l|c|c|c|c|}
\hline \multirow{3}{*}{ Bakteri } & \multirow{2}{*}{ Sampel } & \multicolumn{4}{|c|}{ Rerata Zona hambat (mm) } \\
\cline { 2 - 6 } & & ASB1 & ASB2 & ASB3 & ASB4 \\
\hline \multirow{5}{*}{ S. aureus } & Ekstrak kasar & - & 9,3 & - & - \\
\cline { 2 - 6 } & Fraksi air & - & 16,6 & - & 10,0 \\
\cline { 2 - 6 } & Fraksi methanol & - & 14,0 & 21,3 & 8,0 \\
\cline { 2 - 6 } & Fraksi n-heksana & - & - & - & - \\
\cline { 2 - 6 } & Kontrol (+) & 19,0 & 19,0 & 18,6 & 18,6 \\
\cline { 2 - 6 } & Kontrol (-) & - & - & - & - \\
\hline \multirow{5}{*}{ E. coli } & Ekstrak kasar & - & 10,0 & - & - \\
\cline { 2 - 6 } & Fraksi air & - & 16,0 & - & 8,6 \\
\cline { 2 - 6 } & Fraksi methanol & - & 12,3 & 24,6 & 9,0 \\
\cline { 2 - 6 } & Fraksi n-heksana & - & - & - & - \\
\cline { 2 - 6 } & Kontrol (+) & 19,0 & 13,3 & 19,0 & 18,6 \\
\cline { 2 - 6 } & Kontrol (-) & - & - & - & - \\
\hline
\end{tabular}




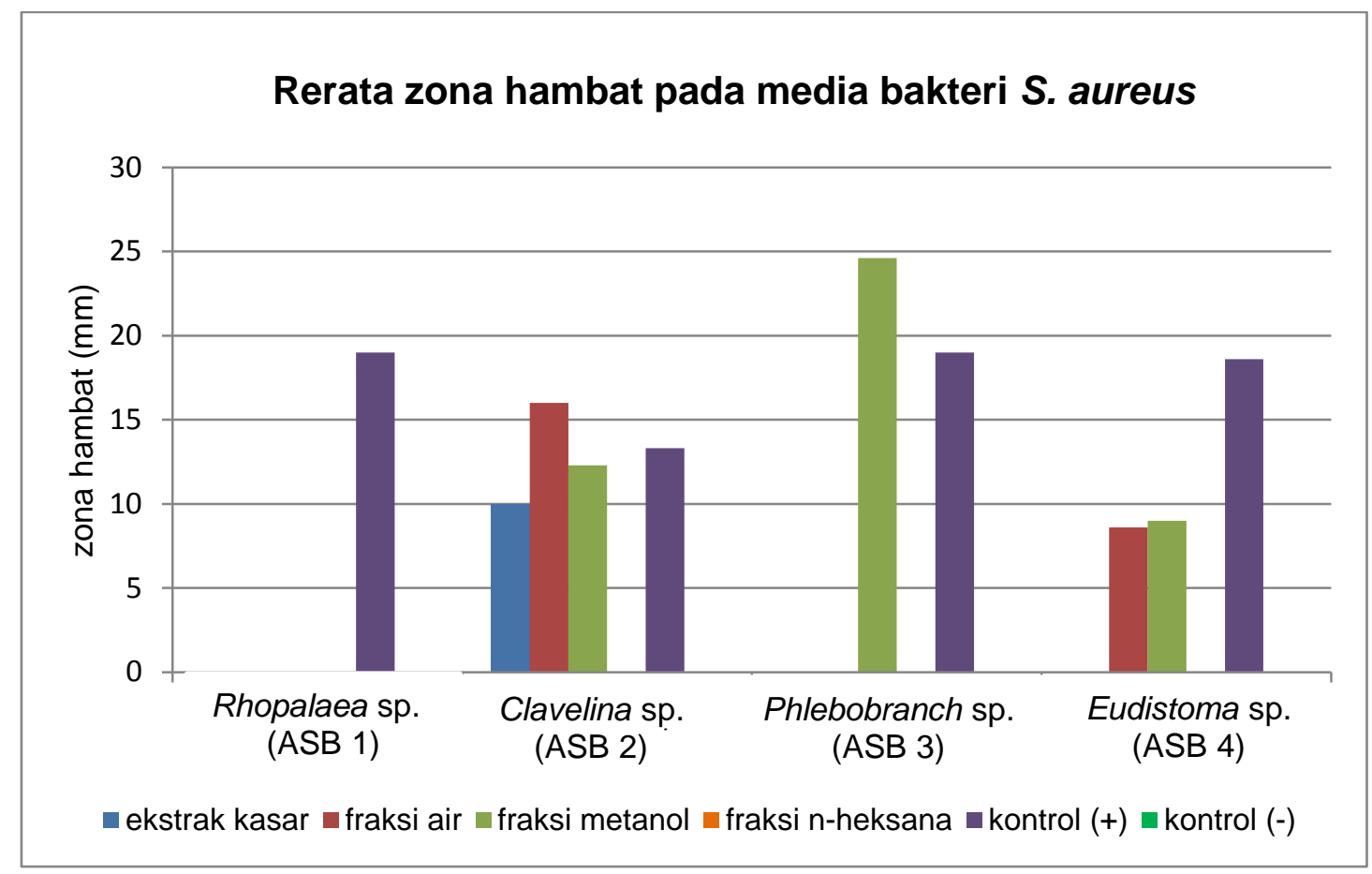

A

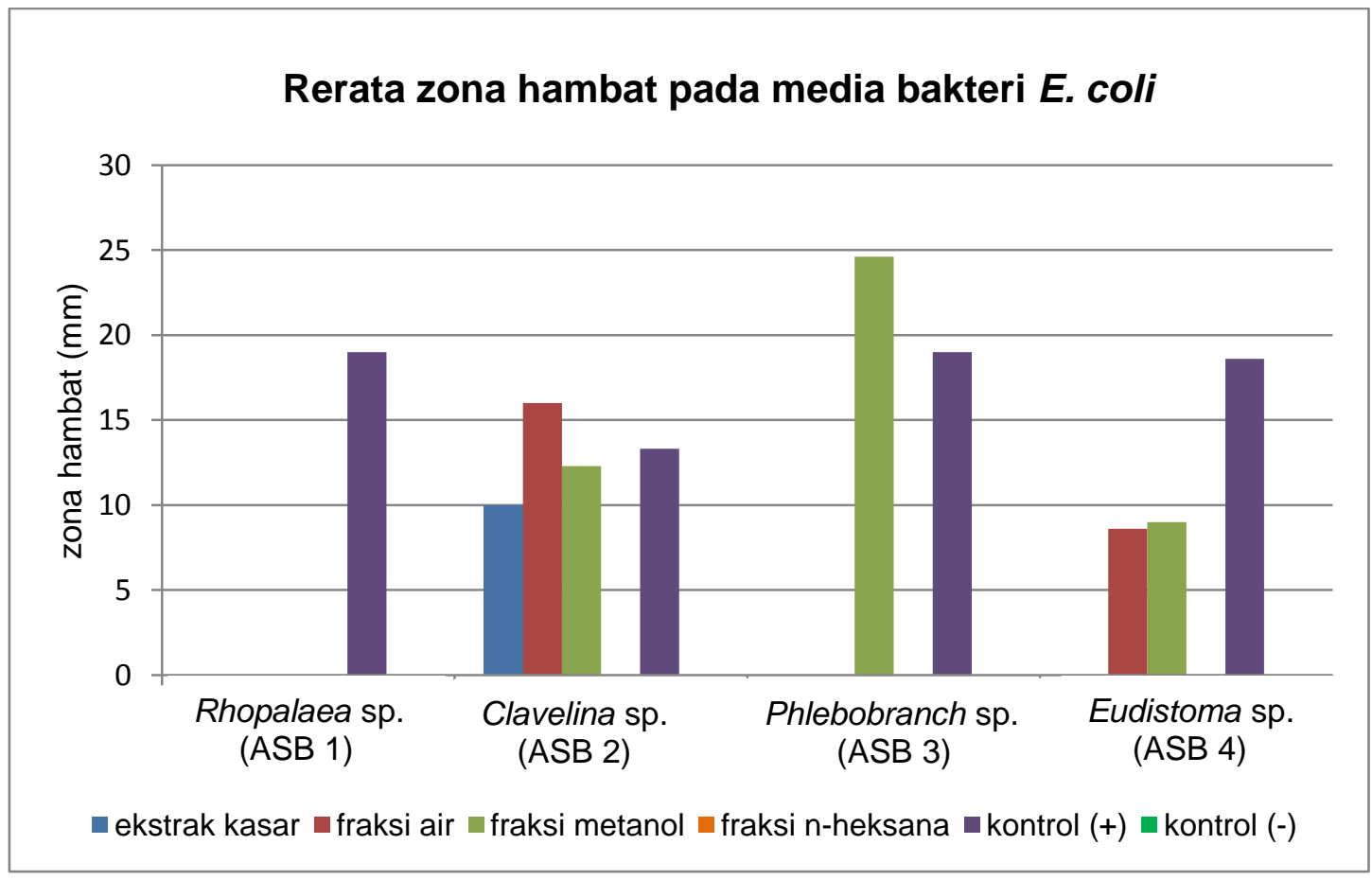

B

Gambar 6. Rerata zona hambat pada media bakteri (A) S. aureus (B) E. coli 
Dari data yang ditampilkan pada tabel 4 dapat dilihat bahwa zona hambat yang dihasilkan dari ekstrak kasar maupun fraksi air ascidian terhadap bakteri $S$. aureus dan E. coli memiliki nilai yang bervariasi namun cenderung sama nilainya jika dibandingkan dengan zona hambat pada kontrol (+) (kloramfenikol). Menurut Davis dan Stout (1971) dalam Wewengkang dkk, (2014) kekuatan aktivitas antibakteri dapat digolongkan sebagai berikut, diameter zona hambat $\leq 5 \mathrm{~mm}$ (lemah), $5-10 \mathrm{~mm}$ (sedang), 10-20 mm (kuat) dan $>20$ mm (sangat kuat).

Berdasarkan tabel 4 Rhopalaea sp. pada ketiga ulangan tidak menunjukkan aktivitas antibakteri baik terhadap bakteri $G$ (+) S. aureus dan G (-) E. coli karena tidak ditemukan zona hambat pada seluruh sampel kecuali kontrol (+) saat dilakukan pengamatan pengujian antibakteri.

Pada Clavelina sp. menunjukkan adanya aktivitas antibakteri terhadap kedua bakteri uji pada sampel ekstrak kasar yang tergolong sedang pada bakteri $S$. aureus $(9,3 \mathrm{~mm})$ dan Pada fraksi air tergolong kuat $(16,6 \mathrm{~mm})$ dan pada fraksi metanol tergolong kuat (14 $\mathrm{mm})$. Sedangkan pada bakteri E. coli sampel ekstrak kasar (10 mm), fraksi air $(16 \mathrm{~mm})$ dan fraksi methanol (12,3 mm) yang tergolong kuat sedangkan pada fraksi n-heksana tidak menunjukan aktivitas antibakteri terhadap pertumbuhan bakteri $G(+) S$. aureus dan bakteri G (-) E. coli karena tidak ditemukan zona hambat. Hal ini di karenakan fraksi n-heksana tidak menunjukan adanya zona hambat pada kedua bakteri uji dari hasil yang diperoleh. Pada ekstrak kasar menunjukan adanya zona hambat pada kedua bakteri uji yaitu $S$. aureus dan E. coli zona hambat yang ditunjukan (tergolong sedang) dibandingkan pada fraksi air dan methanol (tergolong kuat).

Jenis Phlebobranch sp. pada sampel ekstrak kasar, fraksi air, dan fraksi n-heksana tidak menunjukkan aktivitas antibakteri terhadap bakteri G (+) S. aureus dan bakteri G (-) $E$. coli karena tidak ditemukan zona hambat pada seluruh sampel kecuali kontrol (+) saat dilakukan pengamatan pengujian antibakteri. Sedangkan pada fraksi methanol yang tergolong sangat kuat pada bakteri $S$. aureus $(21,3 \mathrm{~mm})$ dan $E$. coli $(24,6 \mathrm{~mm})$.

Jenis Eudistoma sp. menunjukkan adanya aktivitas antibakteri terhadap kedua bakteri uji 
pada fraksi air tergolong sedang (10 $\mathrm{mm}$ ) dan dan pada fraksi metanol tergolong sedang $(8 \mathrm{~mm})$ sedangkan pada fraksi N-heksan tidak menunjukan aktivitas antibakteri terhadap bakteri gram (+) S. aureus karena tidak ditemukan zona hambat. Dan pada bakteri E.coli fraksi air dan fraksi metanol tergolong sedang (8,6 dan $9 \mathrm{~mm}$ ) dan pada fraksi n-heksana tidak menunjukan aktivitas antibakteri terhadap bakteri gram (-) E.coli karena tidak ditemukan zona hambat.

Dari hasil yang ditunjukan daya hambat bakteri dikarenakan struktur dari dinding sel bakteri gram positif lebih sederhana dan lebih mudah senyawa anti bakteri untuk masuk ke dalam sel dan menemukan sasaranya, sedangkan struktur dinding sel dari bakteri gram negatif lebih kompak dan padat (Posangi dan Bara, 2014; Bara dkk. (2015)

Pada penelitian yang telah dilakukan tampak bahwa ketiga ascidian jauh lebih evisien untuk menghambat pertumbuhan bakteri uji tersebut. Dapat dipastikan juga bahwa pelarut yang dipakai sebagai kontrol (-) tidak memberikan pengaruh pada zona hambat yang terbentuk (Patel et al., 2014).
Keempat jenis ascidian yang telah diuji perlu diteliti lebih lanjut untuk dapat menentukan senyawa antibakteri apa yang terkandung dalam ascidian tersebut.

\section{Pengujian Aktivitas Anti-UV}

Dari pengujian antibakteri yang telah dilakukan sebelumnya ditunjukan bahwa fraksi air adalah sampel yang menghasilkan zona hambat terhadap petumbuhan bakteri uji. Maka pada pengujian ini, fraksi air empat jenis ascidian diujikan menggunakan alat UV-1800 SHIMADZU spektrofotometer untuk mengetahui serapan sampel pada $\lambda$ 290-400 nm.

Fraksi air Rhopalaea sp. menunjukkan serapan pada UV-B dengan nilai tertinggi $4 \dot{A}$ pada $\lambda$ 290-300 nm kemudian mengalami penurunan sampai $0,5 \dot{A}$ pada $\lambda 300$ dan tetap stabil sampai $\lambda 400 \mathrm{~nm}$ (UV-A) Gambar 7.

Fraksi air dari Clavelina sp. menunjukan serapan pada UV-B dengan nilai tertinggi $1,9 \dot{A}$ pada $\lambda$ $290 \mathrm{~nm}$ kemudian mengalami penurunan sampai $\lambda 340 \mathrm{~nm}$ dengan nilai serapan $0,7 \dot{A}$ dan tetap konstan sampai $\lambda 400 \mathrm{~nm}$ (UV-A) Gambar 8.

Fraksi air dari Eudistoma sp. menunjukan serapan pada UV-B dan UV-A dengan nilai $0,2 \dot{A}$ pada $\lambda$ 
$290 \mathrm{~nm}$ dan tetap konstan sampai $\lambda$ 400 nm Gambar 9.

Fraksi air dari Plebobranch sp. menunjukan serapan pada UV-B dengan nilai tertinggi $2,1 \dot{A}$ pada panjang $\lambda 290 \quad \mathrm{~nm}$ kemudian mengalami penurunan sampai $\lambda 310$ $\mathrm{nm}$ dengan nilai serapan $0,5 \dot{A}$ tetap konstan sampai $\lambda 400 \mathrm{~nm}$ (UV-A) Gambar 10.

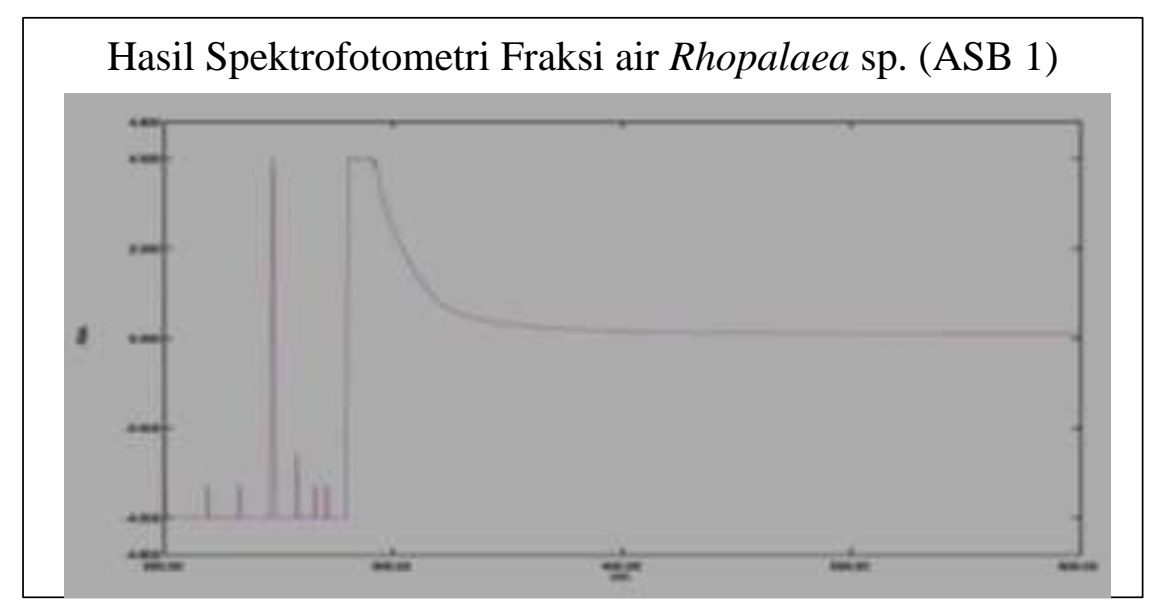

Gambar 7. Hasil Spektrofotometri Fraksi air Rhopalaea sp.

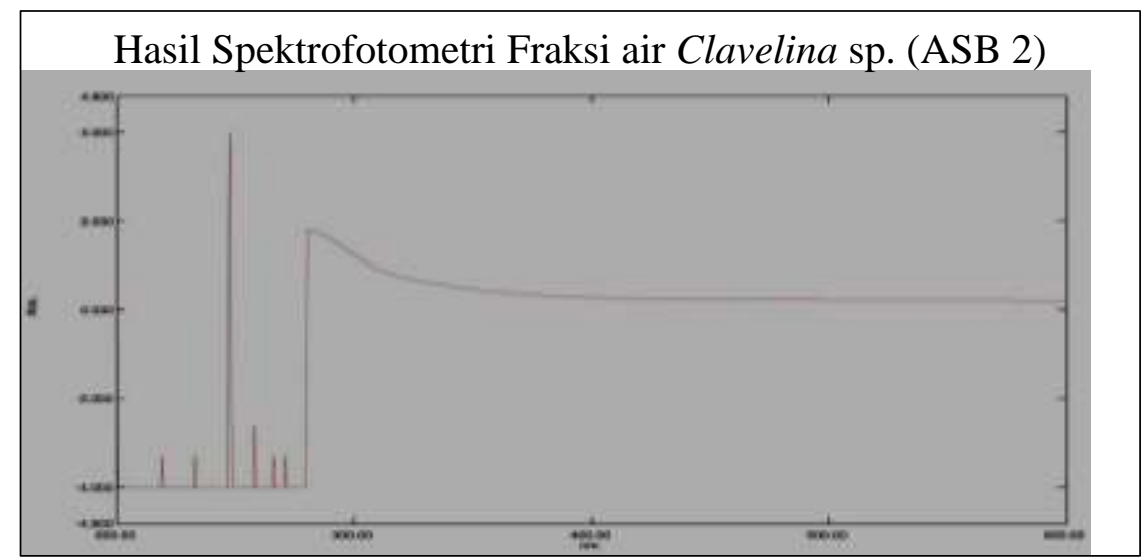

Gambar 8. Hasil Spektrofotometri Fraksi air Clavelina sp. 


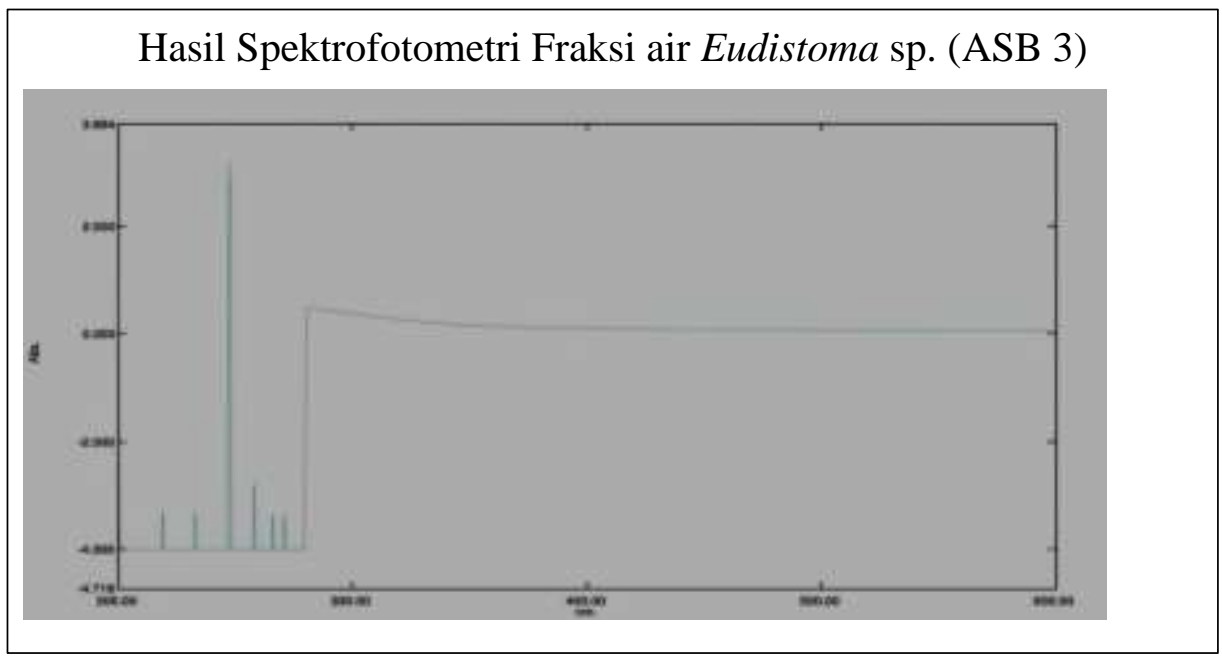

Gambar 9. Hasil Spektrofotometri Fraksi air Eudistoma sp.

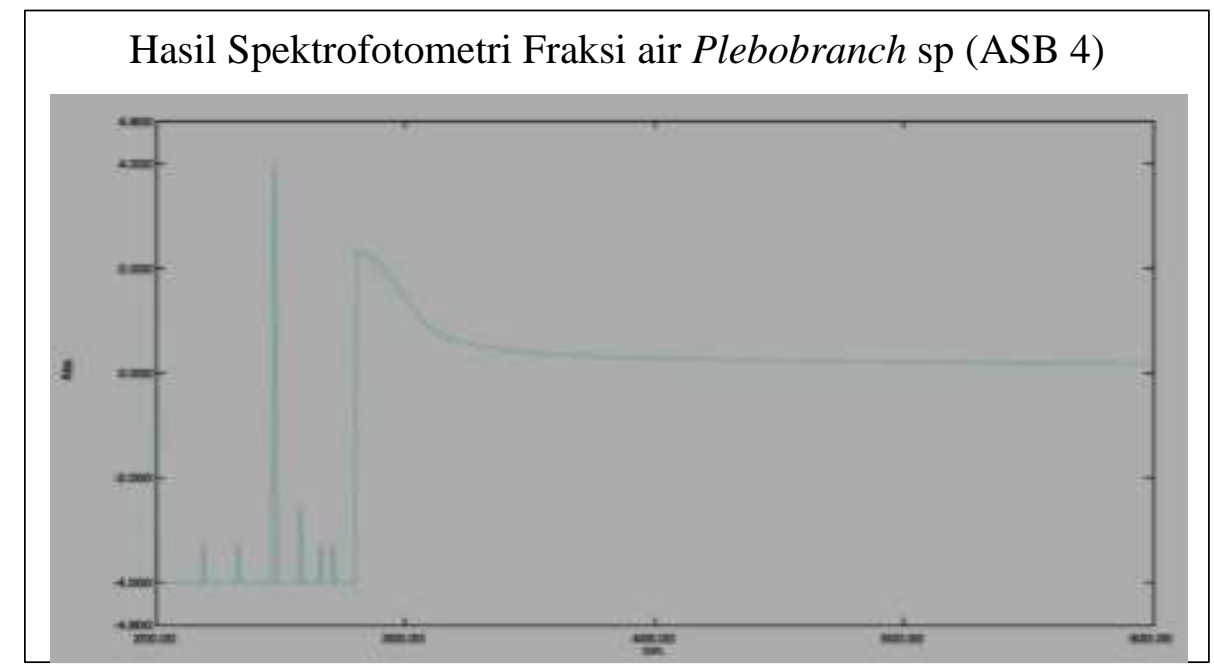

Gambar 10. Hasil Spektrofotometri Fraksi air Plebobranch sp. 
Berdasarkan hasil yang didapatkan melalui pengujian di UV spektrofotometer, keempat fraksi air menunjukan serapan pada UV-B dengan nilai tertinggi $4 \dot{A}$ pada jenis Rhopalaea sp. dan serapan UV-A tertinggi $0,7 \dot{A}$ pada jenis Clavelina sp. sedangkan serapan UV-B dan UV-A terkecil ditunjukkan oleh Ascidian jenis Eudistoma sp. 0,2 $\dot{A}$.

\section{KESIMPULAN}

Dari keempat ekstrak ascidian didapatkan Aktivitas antibakteri dengan zona hambat terbesar pada Clavelina sp., Plebobranch sp., Eudistoma sp. Lebih efektif dalam menghambat pertumbuhan bakteri uji Staphylococcus aureus dan Escherichia coli.

Berdasarkan hasil dari keempat fraksi air menunjukan serapan pada UV-B dengan nilai tertinggi 4 Ȧ pada jenis Rhopalaea sp. dan serapan UV-A tertinggi $0,7 \dot{A}$ pada jenis Clavelina sp. sedangkan serapan UV-B dan UV-A terkecil ditunjukkan oleh Ascidian jenis Eudistoma sp. $0,2 \dot{A}$ melalui spektrofotometer-UV Vis. Seluruh sampel fraksi air keempat jenis ascidian menunjukkan serapan UV-B dan UV-A.

\section{DAFTAR PUSTAKA}

Bara, R. A., G.D. Kandou, ARB. Ola, J. Posangi. 2015. Analisis Senyawa Antibioti Dari jamur Simbion Yang Terdapat Dalam Ascidian Didemnum molle Disekitar Perairan Bunaken
Sulawesi Utara. Jurnal LPPM Bidang Sains dan Teknologi.2(2) hal 7-8.

Gosliner, T., Baherens, D. W., dan Williams, G. C. 1996. Coral Reef animals of the IndoPacific: animal life from Africa to Hawai exclusive of the vertebrates. Sea Challengers.

Kumayas, A.R., Wewengkang S.D., dan Sudewi S.,2015. Aktifitas antibakteri dan karakteristik gugus fungsi dari tunikata polycarpa aurata. Pharmacon Jurnal Ilmiah Farmasi UNSRAT

McClintock, J. B., dan Baker, B. J. 2001. Marine chemical ecology. CRC press.

Mujipradhana,V.N.,Wewengkang,D.

S. Suryanto, E., 2018, Aktivitas Antimikroba dari Eksrak Ascidian Herdmania momus pada mikroba patogen Manusia. PHARMACON Jurnal Ilmiah Farmasi UNSRAT.

Madigan, M. T. dan Martinko, J.M. 2006. Brock: Biology of Microorganisms $11^{\text {th }}$ Edition. Pearson Prentice Hall. New Jersey, USA.

Munif, A. 2009. Eschericia coli Disekitar Air Minum Kita. Environmental Sanitation Jurnal.

Ortez, J. H. 2005. Disk Diffusion Testing in Manual of Antimicrobial Susceptibility testing. Marine B. Coyle (Coord. Ed). American society ForMicrobiology.

Opa, S., Bara, R., Gerung, G., Rompas, R., Lintang, R., dan Sumilat, D. 2018. Aktivitas antibakteri fraksi n-heksana 
metanol dan air ddari ascidian Lissolinum sp. Jurnal Pesisir dan Laut Tropis, 1(1): hal. 6980.

Patel, J.B., F.R. Cokerill, J. Alder, P.A. Bradford, G.M. Eliopoulos, D.J. Hardy, J.A.Hindler, S.G. Jenkins, J.S. Lewis, L.A. Miller, M. Powell, J.M. Swenson, M.M.Traczewski, J.D. Turnidge, M.P. Weinstein, B.L. Zimmer. 2014. Performance Standards for Antimicrobal Susceptibility Testing; Twentyfourth Informational

Supplement. Vol.34. Clinical dan Laboratory Standards Insitute. Hal 30-40.

Warouw, V. dan Losung, F. 2015. Potensi Substans Anti-uv Dari Serangga Laut Family Gerridae Di Tasik Ria Mokupa Manado, Sulawesi Utara. Jurnal LPPM Bidang Sains dan Teknologi, 2(2): hal. 95-102.

Wewengkang, D.S., Sumilat, D.A., dan Rotinsulu, H. 2014. Sitotoksisitas Ekstrak Kasar Ascidian dari Pulau Bunaken. Jurnal LPPM Bidang Sains dan Teknologi. 1(1) :hal86-89.

Yuwono, H. 2012. Staphylococcus aureus dan MethicilinResistant Staphylococcus aureus (MRSA). Palembang : Departemen Mikrobiologi FK UNSRI. 